\title{
PRISMA Flowchart
}

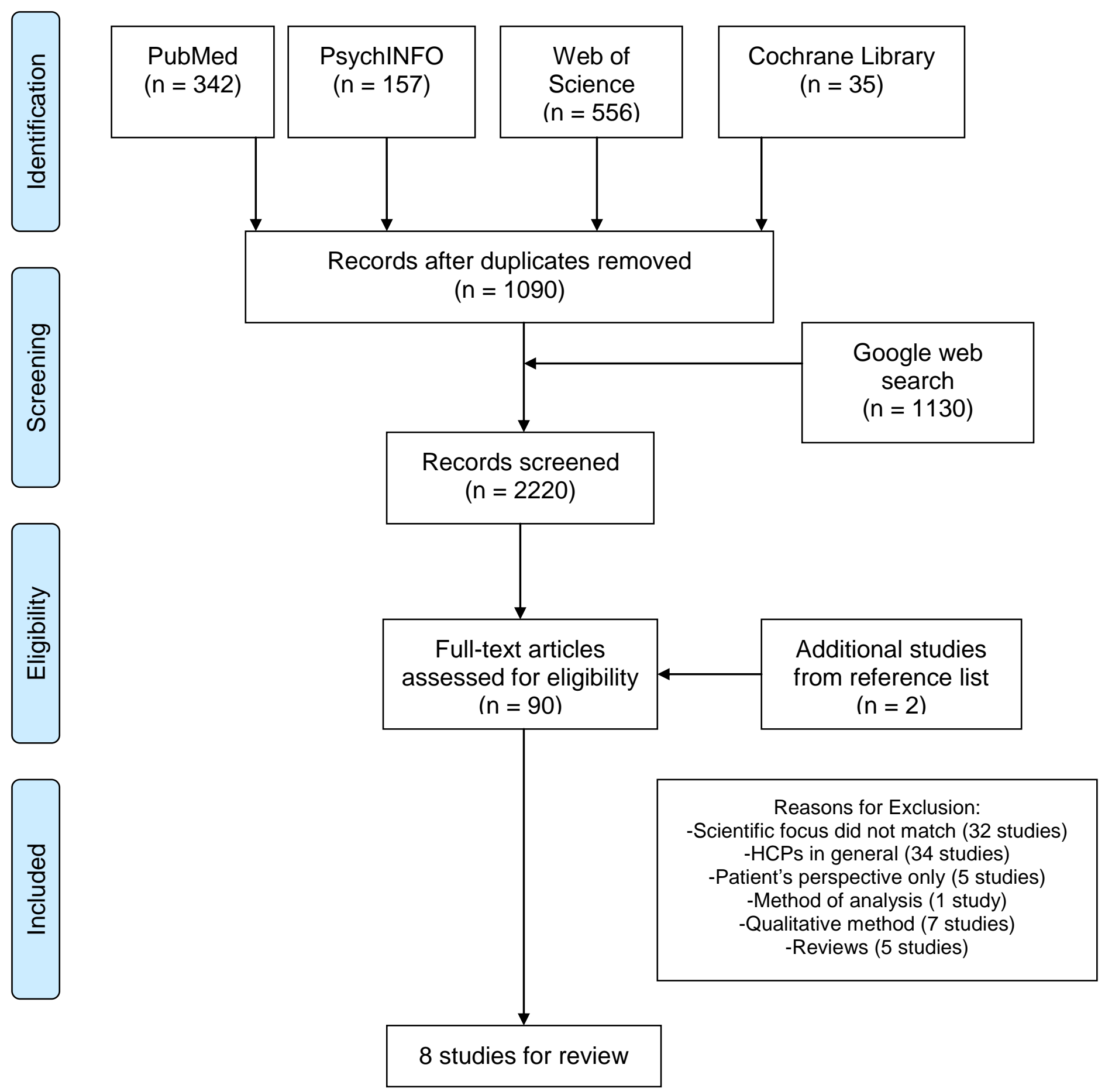

